\title{
ГЕНЕТИКА ЧЕЛОВЕКА
}

DOI: $10.32521 / 2074-8132.2019 .2 .107-115$

Козлов А.И., ${ }^{1,2)}$, Остроухова И.О. ${ }^{3)}$, Лавряшина М.Б. ${ }^{4}$, Вершубская Г.Г. ${ }^{1,2)}$, Ульянова М.В. ${ }^{3)}$

1) МГУ имени МВЛомоносова, НИИ и музей антропологии, 125009, ул. Моховая, д. 11, Москва, Россия;

2) Институт возрастной физиологии РАО,

119121, ул. Погодинская, 8, крп.2, Москва, Россия;

3) ФГБОУ ВО Кемеровский государственный университет,

650000, ул. Красная, 6, г. Кемерово, Россия;

4) ФГБОУ ВО Кемеровский государственный медиинский университет,

650056, ул. Ворошилова, 22A, Кемерово, Россия

\section{АНТРОПОЭКОЛОГИЧЕСКАЯ СПЕЦИФИКА ПОЛИМОРФИЗМА ГЕНОВ, ВЛИЯЮЩИХ НА МЕТАБОЛИЗМ КОСТНОЙ ТКАНИ (НА ПРИМЕРЕ ПОПУЛЯЩИИ ШОРЦЕВ)}

Введение. На примере группы горно-таёжных шориев рассматривается связь полиморфизма генов, влияющих на метаболизм костной ткани, с характером среды обитания и особенностями традиционного питания.

Материалы и методы. Материал для молекулярно-генетического исследования собран в популяции шорцев Кемеровской области. Обследовано 72 человека (37 мужчин, 35 женщин). Проведено типирование генов VDR Bsml rs1544410, VDR Fok1 rs2228570, TREH rs2276064 u LCT rs4988235. Анализ этнографрической литературы позволил уточнить набор составлявших основу традиционной пищи шорцев продуктов и основные источники их получения.

Результаты и обсуждение. На широте Южной Сибири $\left(52^{\circ} \mathrm{CW}\right)$ организм не может синтезировать необходимый объём холекальциферола D3 на протяжении всего года. Источников эргокальцифрерола D2 в традиционной диете шорцев было немного: пресноводная рыба, кобылье и овечье молоко обеспечивали лишь минимальное поступление витамина $D$ в организм. Грибы, потенциальный источник D2, не являлись существенным элементом традиционной кухни шорцев. С этим согласуется очень высокое, по сравнению с другими группами, носительство генотипов AA*TREH (6,9\%) и AG*TREH (27,8\%), ассоциированных с минимальной и сниженной активностью фермента трегалазы, необходимой для усвоения грибного сахара трегалозы (мукозы). Таким образом, популяция испытывала недостаток витамина $D$.

Молоко домашних животных, как источник кальция, занимало малое место в традиционной диете: до 1930-х годов коров в шорских хозяйствах не было. Генотип CC*LCT, детерминирующий ограниченную активность лактазы и неспособность к усвоению молока взрослыми, мы обнаружили у 73,6\% шорцев. Это высокая частота: в различных группах русских доля гомозигот *CС варьирует в пределах 40-50\%. Малая доступность молока и недостаток других кальцийсодержащих продуктов были фоактором риска недостаточной минерализации костной ткани, что согласуется с антропологическими материалами.

Ответом на давление негативных фракторов стало увеличение в генофонде доли носителей генотипов VDR CC*Fok1 (44,4\%), CT*Fok1 (15,3\%), GA*Bsml (48,6\%), ассоциированных с повышенным усвоением кальция в кости.

Заключение. Адаптацию шорцев к экологическим условиям с низкой доступностью витамина $D$ и кальцийсодержащих продуктов обеспечило повышение чувствительности рецепторов тканей к витамину $D$.

Ключевые слова: антропология; генетика; питание; минерализация кости; рецептор витамина D; эргокальциферол D2; холекальциферол D3; лактаза; трегалаза

АНТРОПОЛОГИя № 2/2019: 107-115

Anthropology, 2019, no. 2, pp. 107-115
Вестник Московского университета. Серия ХХIII Moscow University Anthropology Bulletin 


\section{Введение}

Гомеорез костной ткани обусловлен балансом нескольких составляющих - синтезом в организме стероидного прогормона холекальциферола D3, поступлением с продуктами кальция и витамина D2 (эргокальциферола), а также чувствительностью тканей к физиологически активному метаболиту эрго- и холекальциферола - 25-гидроксивитамину $\mathrm{D}$, или 25(OH)D, являющимся одновременно основным депо витамина [Козлов, Вершубская, 2017].

Считается, что более половины потребностей организма человека в витамине D покрывается за счёт холекальциферола [Brot et al., 2001], однако его поступление зависит от климатических условий. В наиболее общем виде можно принять, что на территориях севернее $35^{\circ} \mathrm{CШ}$ (широта Северной Афррики) уровень ультрафиолетового облучения недостаточен для круглогодичной продукции D3 в объёме, необходимом для поддержания нормального статуса костной ткани [Kozlov, Vershubskaya, 2017]. Поэтому по мере заселения северных регионов всё большее значение для регуляции костного метаболизма приобретал «истинный» витамин D - эргокальцифрол, синтез которого в организме человека невозможен.

Основные природные источники эргокальциферола - рыба и грибы, в тканях которых накапливается D2. B меньшей степени эргокальциферол поступает с молоком: с ним человек может получить ещё 4-10\% необходимой суточной дозы. Важнее роль молока как поставщика кальция: в современном мире молоко и молочные продукты покрывают до $50 \%$ суточной потребности человека в этом минеральном веществе. Кроме того, содержащаяся в молоке лактоза облегчает усвоение кальция, способствуя переводу его в растворимую фрорму [Ingram et al., 2009; Smith, 2009].

Регулярное употребление в пищу грибов и молока возможно только при достаточной активности ферментов, воздействующих на содержащиеся в этих продуктах дисахариды - «грибной сахар» трегалозу (мукозу) и «молочный сахар» лактозу. Всасывание в кишечнике этих сложных сахаров (дисахаридов) возможно только после расщепления их до моносахаридов. Эту функцию выполняют фрерменты лактаза и трегалаза, продукция и активность которых генетически детерминированы. У индивидов с недостаточностью трегалазы и лактазы после употребления в пищу молока развиваются диспепсические явления в виде болей в животе и расстройств кишечника.

Также под генетическим контролем находится чувствительность тканей и органов-мишеней к 25(OH)D.

Исходя из изложенного, можно ожидать, что адаптация к экологическим условиям с низкой доступностью витамина D и кальцийсодержащих продуктов отразится в распределении аллелей и генотипов, детерминирующих чувствительность тканей к витамину D и активность ферментов, влияющих на поступление эргокальциферола и кальция.

Цель настоящей работы - рассмотреть связь полиморфизма влияющих на гомеорез костной ткани генов с характером среды обитания и особенностями традиционного питания на примере группы горно-таёжных шорцев.

Поскольку до первой половины XX века шорцы сохраняли ряд элементов традиционного уклада жизни и питания, а малая транспортная доступность в тот период способствовала определённой генетической изолированности, исследование этой группы может существенно пополнить информацию о древних генофондах народов Южной Сибири и специфике частот детерминирующих метаболизм генов в сибирских популяциях.

\section{Материалы и методы}

Согласно современным представлениям, в основе генофонда шорцев лежит палеоевропеоидный субстрат, присущий автохтонному населению Западной Сибири и Урала [Балановская с соавт., 2014]. C середины VI по начало X века древние родичи самодийцев, угров, и, возможно, кетов, смешивались с пришлыми тюркоязычными племенами, что, в конечном итоге, привело к формированию группы, ныне известной как шорцы [Кимеев, 2014а]. Нашим исследованием охвачена южная, горнотаёжная группа, которую далее для краткости мы обозначаем как «шорцы».

Материал для молекулярно-генетического исследования собран в ходе экспедиционного обследования шорцев Таштагольского района Кемеровской области. Согласно сложившейся практике [Балановская с соавт., 2016], в выборку включались неродственные индивиды, все предки которых на протяжении не менее трех поколений относили себя к данному народу и проживали в ареале данной популяции. Генеалогические данные получены со слов обследованного. Суммарный объем выборки - 72 человека (37 мужчин, 35 женщин).

Сбор биологических образцов (кровь, буккальный эпителий) сопровождался получением информированного согласия на участие в исследовании (форма документа утверждена Комитетом по этике Кемеровского госуниверситета). ДНК из биологических материалов выделяли методом фенол-хлороформной экстракции. Концентрацию ДНК промеряли на спектрофотометре NanoDrop 2000С. Генотипирование по панели ДНК-маркеров генов VDR Bsml rs1544410, VDR Fok1 rs2228570 
(синоним rs10735810), TREH rs2276064 и LCT rs4988235 проводили полимеразно-цепной реакцией (ПЦР) в режиме реального времени на амплификаторе ПЦР Bio-Rad CFX96 Touch.

Расчет и последующая обработка результатов осуществлялись при помощи программы Statistica 8.0 и ряда оригинальных программ для анализа популяционно-генетических данных.

Анализ этнографической литературы позволил уточнить набор составлявших основу традиционной пищи шорцев продуктов и основные источники их получения.

Хотя коренное население Горной Шории с начала XVII века всё теснее контактировало с русскими переселенцами в «Кузнецкую волость», шорцы ещё в первой половине $X X$ столетия сохраняли многие элементы традиционного хозяйственного уклада [Потапов, 1950; Кимеев, 2014б]. Однако реконструкция основных элементов традиционного питания шорцев оказалась непростой задачей. И.Д. Фролова справедливо указывает на отсутствие монографических работы, посвящённых питанию южносибирских народов [Фролова, 2007]. Значительный массив современных публикаций представлен статьями и книгами описательного характера, в которых "традиционное питание» сводится к сильно русифрицированным продуктам и блюдам. Подобная информация (ссылок на исключённые из рассмотрения работы мы не приводим) представляет ограниченный интерес для специалиста, которому необходимо выявить элементы питания, отражающие достаточно древние хозяйственно-культурные и экологические адаптации рассматриваемой группы. Только это позволит понять, какие из морфофиизиологических комплексов, связанных с процессом усвоения пищи, имели адаптивный характер и закрепились в генофонде популяции.

В результате мы ограничили круг источников теми, которые позволяют составить представление о питании шорцев в XVIII-XIX веках и ранее [Ядринцев, 1891; Потапов, 1936; Потапов, 1950; Радлов, 1989; Улагашева, 1997; Огурцов, 2008; Селезнев, 2009; Кимеев, 2014а; Кимеев, 2014б].

Комплексная антропоэкологическая характеристика региона традиционного проживания шорцев приводится по работам [Атлас..., 1995; Антипова, 2001; Антропоэкология..., 2005].

\section{Результаты}

Распределение в выборке шорцев частот аллелей и генотипов, детерминирующих чувствительность органов-мишеней к витамину D (VDR Bsml, Fok1) и особенности активности ферментов-дисахаридаз
Таблица 1. Распределение в выборке шорцев частот аллелей генов VDR (Fok1, Bsml), LCT и TREH Table 1. Allele frequencies of VDR (Fok1, Bsml), LCT, and TREH genes in the studied group of Shors

\begin{tabular}{|l|c|l|c|}
\hline \multicolumn{2}{|c|}{$V D R(F o k l)$ rs2228570 } & \multicolumn{2}{c|}{$V D R(B s m I) r s 1544410$} \\
\hline Аллель & Частота \pm s.e. & Аллель & Частота \pm s.e. \\
\hline $\mathrm{C}$ & $0,662 \pm 0,041$ & $\mathrm{G}$ & $0,650 \pm 0,040$ \\
\hline $\mathrm{T}$ & $0,338 \pm 0,041$ & $\mathrm{~A}$ & $0,350 \pm 0,040$ \\
\hline \multicolumn{2}{|c|}{ LCT rs 4988235} & \multicolumn{2}{c|}{ TREH rs 2276064} \\
\hline Аллель & Частота \pm s.e. & Аллель & Частота \pm s.e. \\
\hline $\mathrm{C}$ & $0,845 \pm 0,030$ & $\mathrm{G}$ & $0,786 \pm 0,035$ \\
\hline $\mathrm{T}$ & $0,155 \pm 0,030$ & $\mathrm{~A}$ & $0,214 \pm 0,035$ \\
\hline
\end{tabular}

Таблица 2. Распределение в выборке шорцев частот генотипов, детерминирующих чувствительность тканей к витамину D (VDR) и продукцию лактазы (LCT) и трегалазы (TREH) Table 2. Genotype frequencies of genes that determine tissue sensitivity to vitamin D (VDR), and production of lactase (LCT) and trehalase (TREH) in the studied group of Shors

\begin{tabular}{|l|c|c|l|l|c|}
\hline \multicolumn{3}{|c|}{ VDR (Fokl) rs2228570 } & \multicolumn{3}{c|}{ VDR (BsmI) rs 1544410 } \\
\hline Генотип & $\mathrm{N}$ & $\% \pm$ s.e. & Генотип & $\mathrm{N}$ & $\% \pm$ s.e. \\
\hline CС & 29 & $40,3 \pm 0,91$ & GG & 29 & $38,9 \pm 0,89$ \\
\hline СТ & 32 & $44,4 \pm 0,89$ & GA & 32 & $48,6 \pm 0,95$ \\
\hline TT & 11 & $15,3 \pm 0,98$ & AA & 11 & $9,7 \pm 0,94$ \\
\hline \multicolumn{3}{|c|}{ LCT rs 4988235} & \multicolumn{3}{c|}{ TREH rs 2276064} \\
\hline Генотип & $\mathrm{N}$ & $\% \pm$ s.e. & Генотип & $\mathrm{N}$ & $\% \pm$ s.e. \\
\hline СС & 53 & $73,6 \pm 0,93$ & GG & 45 & $62,5 \pm 0,91$ \\
\hline СТ & 14 & $19,4 \pm 0,29$ & GA & 20 & $27,8 \pm 0,9$ \\
\hline TТ & 4 & $5,6 \pm 0,17$ & AA & 5 & $6,9 \pm 0,97$ \\
\hline
\end{tabular}

(гены лактазы LCT; трегалазы TREH) представлено в таблицах 1 и 2.

Рассматриваемые гены обеспечивают адаптивный ответ на комплекс средовых воздействий абиотического (уровень инсоляции, температурный режим и т.п.) и биотического характера (пища животного и растительного происхождения, обеспечивающая поступление нутриентов и энергии). Соответственно, необходимо систематизировать основные антропоэкологические и этнографические материалы, характеризующие среду обитания и особенности традиционного питания шорцев.

Исконный регион обитания группы характеризуется пересечённым среднегорным рельефром с высокой залесённостью и относительно мягко проявляющейся континентальностью климата. Согласно интегральной оценке по параметрам термического баланса территории, контрастности климата, длительности зимы, числа дней с ветром в зимний период, южная часть современной Кемеровской области (включая Горную Шорию) относится к регионам с комфортным для сельского 
населения климатом и высоким уровнем инсоляции [Атлас..., 1995; Антипова, 2001; Антропоэкология..., 2005].

Адаптация к этим условиям привела обитателей горной тайги к формированию комплексного полуоседлого характера жизнеобеспечения, сходного со сложившимся в других лесо-таёжных регионах бореального пояса [Ядринцев, 1891]. Производящее хозяйство было развито слабо. Судя по материалам XVIII в., большинство хозяйств шорцев «питалось более одним звериным мясом», докупая хлеб у русских крестьян (приводится по [Кимеев, 2014б]). Полукочевое (отгонное) скотоводство основывалось на разведении овец и лошадей, от которых получали умеренное количество молока. Крупный рогатый скот не держали, поскольку глубокие снега исключали возможность зимней пастьбы [Радлов, 1989]. В целом «домашний скот был редкостью» [Потапов, 1950, с. 124].

Небогатая продукция земледелия и животноводства дополнялась добычей, которую обеспечивала пешая (зимой на лыжах) охота в таёжной зоне. Существенный вклад вносил вылов речной рыбы мелких пород, которую в том или ином виде включали в состав разнообразных блюд, а также щуки, хариуса, тайменя, налима, язя [Потапов, 1936; Улагашева, 1997].

Важной составляющей жизнеобеспечения шорцев был сбор дикоросов, преимущественно клубневых и корневых частей растений [Радлов, 1989; Улагашева, 1997]. Подчеркнём при этом, что в этнографических материалах мы не обнаружили упоминаний о наличии грибов в традиционной кухне шорцев.

\section{Обсуждение}

Несмотря на то, что по числу солнечных дней в году Южная Сибирь относится к наиболее благоприятным регионам России [Атлас..., 1995; Антипова, 2001], в столь северных широтах $\left(52^{\circ} \mathrm{CШ}\right)$ организм не может синтезировать необходимый объём холекальциферола D3 на протяжении всего года [Kozlov, Vershubskaya, 2017]. Для поддержания относительно стабильного D-витаминного статуса человек должен получать с пищей значительное количество эргокальциферола D2.

Однако источников D2 в традиционной диете шорцев было немного. Пресноводная рыба содержит мало эргокальциферола, молоко домашних животных обеспечивает лишь минимальное поступление витамина в организм [Химический состав..., 1979; Souci, Fachmann, Kraut, 1989]. Информации о наличии в традиционной диете шорцев такого природного источника витамина D2, как грибы, в этнографических источниках мы не обнаружили. Согласно данным нутрициологических исследований, грибы не входят и в рацион современных шорцев [Цыганкова с соавт., 2016].

Конечно, отсутствие упоминаний об употреблении в пищу того или иного продукта не означает, что он был действительно исключён из состава традиционных блюд, но тем не менее, данные генетики косвенно подтверждают предположение о том, что грибы не были существенным элементом традиционной кухни шорцев. Об этом говорит очень высокая частота носительства аллеля А гена трегалазы TREH (табл. 1). Фермент трегалаза необходим для расщепления и последующего усвоения содержащейся в грибах трегалозы (микозы, или грибного сахара) [Richards et al., 2002]. Замена $\mathrm{G} \rightarrow \mathrm{A}$ в локусе rs2276064 гена TREH приводит к снижению активности фермента: у гетерозигот AG активность фермента снижена вдвое, а у гомозигот АА - в три раза по сравнению с носителями варианта GG [Muller et al., 2013]. B африканских популяциях аллель TREH*A имеют в среднем 0,6\% населения, в европейских - 1,9\%, в Южной Азии - 4,4\%, но у коренного населения Севера его носительство в 7-13 раз выше, чем в популяциях Дальнего Востока, и в 15-30 раз - по сравнению с европейскими группами [Малярчук, Деренко, 2017]. В нашей выборке 6,9\% шорцев имеют генотип $A A^{*} T R E H$, и 27,8\% - $A G^{*} T R E H$, то есть обладают, соответственно, минимальной и сниженной активностью трегалазы (табл. 2). Наличие аллеля TREH*A у $21 \%$ представителей немногочисленной выборки неродственных индивидов (табл. 1) - чрезвычайно высокий показатель. Трактовать его можно в рамках выдвинутой ранее гипотезы [Kozlov et al., 2005]: закрепление в популяции аллеля А отражает ослабление отбора на поддержание «дорогостоящей» продукции фермента в условиях, при которых необходимость в нём невысока из-за малой или редкой потребности в усвоении данного нутриента. Так или иначе, генетические данные согласуются с предположением о том, что при традиционном варианте питания грибы, по меньшей мере, редко включались шорцами в пищу, а это сужало круг источников эргокальциферола D2.

Итак, учитывая сравнительно невысокий и непостоянный на протяжении года уровень УФ-радиации и особенности питания (потребление речной рыбы с относительно низким содержанием эргокальциферола и малое употребление или отсутствие в рационе грибов), можно заключить, что при традиционном образе жизни шорцев доступность витамина D в фрорме как холекальциферола D3, так и эргокальциферола D2, была одним из факторов, лимитирующих гомеорез костной ткани. Это 
предположение согласуется с данными о пониженной минерализации костной ткани у шорцев [Антропоэкология..., 2005].

Недостаток витамина как регулятора минерального обмена в костной ткани может частично компенсироваться повышенным поступлением с пищей необходимого для нормального костного метаболизма кальция.

Одним из кальцийсодержащих продуктов в традиционной кухне шорцев была рыба. Однако вклад её не мог быть значительным, поскольку ткани пресноводных видов (за исключением карповых) содержат сравнительно мало кальция. Учитывая это, основным источником поступавшего с пищей кальция следует считать молоко овец и лошадей и изготовленные из него молочные продукты. Овечье молоко характеризуется высокой концентрацией кальция (179 мг на 100 г продукта), хотя в кобыльем молоке его содержание в три раза ниже [Химический состав..., 1979; Souci, Fachmann, Kraut, 1989].

Значение цельного молока как источника кальция ограничивалось двумя обстоятельствами. Во-первых, оно было сезонным продуктом, доступным на протяжении 100-120 дней дойного сезона (который приходился на наиболее «солнечное» время года, в силу повышенного УФ-облучения благоприятное для аутосинтеза холекальциферола D3). Вторым, более существенным фактором, является высокая частота носителей генотипа $C C^{*} L C T$ в популяции шорцев (табл. 2). До одомашнивания молочного скота в популяцияx Homo sapiens отбором поддерживалось носительство указанного генотипа, детерминирующего первичную гиполактазию - снижение продукции фермента по мере взросления. Признак был благоприятным: отказ подрастающих детей от материнского молока повышал шансы женщины на последующую беременность и выкармливание очередного потомка. После одомашнивания молочного скота, селективное преимущество получили носители мутантного аллеля T*LCT, у которых выработка лактазы с возрастом не снижается, а молоко и молочные продукты на протяжении всей жизни могут оставаться дополнительным источником кальция. Это особенно важно во внутриконтинентальных регионах с низким уровнем ультрафиолетового облучения и недостатком продуктов, богатых витамином D [Козлов, Вершубская, 2017].

Генотип $C C^{*} L C T$, детерминирующий ограниченную активность лактазы и малую способность к усвоению молока взрослыми, мы обнаружили у 73,6\% шорцев (табл. 2). Это высокая частота признака: для сравнения укажем, что доля гомозигот *CС в различных территориальных группах русских варьирует в пределах 40-50\% [Соколова с соавт., 2007; Коз- лов, 2019]. Наши результаты корреспондируют с данными нутрициологического исследования населения Горной Шории, которые показывают, что молоко употребляется шорцами 1-2 раза в месяц либо вообще исключается из рациона [Цыганкова с соавт., 2016].

Итак, источники кальция и витамина D при традиционном природопользовании и питании шорцев были ограниченны. Однако на биологическом уровне оставался такой вариант адаптации, как повышение чувствительности органов-мишеней к физиологически активным метаболитам витамина. Эту функцию обеспечивает внутриклеточный (ядерный) рецептор витамина $D$, активность которого определяется полиморфным геном VDR [Suda et al., 2003; Uitterlinden et al., 2004]. Этот ген локализован в 12-й хромосоме и состоит из 11 экзонов.

В экзоне 2 локализована нуклеотидная последовательность Fok1 (rs2228570), содержащая инициирующий трансляцию полиморфный кодон. Вариант, при котором исходное основание тиамин (Т) заменено на цистеин (C), приводит к синтезу укороченной полипептидной цепи (424 аминокислоты вместо 427 , т.е. на три меньше), которая в 1,7 раза активнее, чем удлиненный вариант [Ames et al., 1999].

Выборка шорцев характеризуется очень высоким носительством аллеля C*Fok1 $(66,2 \%)$ и генотипов CC*Fok1 и CT*Fok1 (табл. 1, 2), значимо превосходя обследованных ранее коми и уроженцев Европейской части РФ [Kozlov et al., 2014; Kozlov, Vershubskaya, Negasheva, 2017].

Имеются также сведения о влиянии на метаболизм костной ткани полиморфизма гена VDR Bsml (rs1544410). В северных европеоидных группах (русские, коми) носительство гомозиготного варианта $A A^{*} B s m l$ ассоциировано со снижением эффективности абсорбции кальция по сравнению с гомозиготами *GG и особенно гетерозиготами *GA [Kozlov et al., 2014; Kozlov, Vershubskaya, Negasheva, 2017]. Эти наблюдения согласуются с данными, полученными в других выборках Северной Европы [Dawson-Hughes et al. 1995; Ferrara et al., 2002; Grundberg et al., 2004].

Доля гетерозигот $G A^{*} B s m /$ в выборке шорцев $(48,6 \%)$ находится на верхней границе частот, описанных в группах русских и восточных финннов [Тагиева с соавт., 2005; Бабенко с соавт., 2008; Мякоткин с соавт., 2011; Козлов, Вершубская, Негашева, 2016], шведов [Grundberg et al., 2004], евроканадцев и северных индейцев кри [Larcombe et al., 2008].

Можно заключить, что для шорцев характерно носительство генотипов VDR (Fok1 и Bsml), acсоциированных с повышенной чувствительностью органов-мишеней к витамину D.
АНТРОПОЛОГИЯ № 2/2019: 107-115 Anthropology, 2019, no. 2, pp. 107-115
Вестник Московского университета. Серия ХХIII Moscow University Anthropology Bulletin 


\section{Заключение}

На основании полученных материалов и проведённого анализа можно сделать следующие выводы.

Природные и культурно-хозяйственные условия жизни древних и близких к современности горных шорцев (как минимум до конца XIX в) оставались неоптимальными в плане обеспечения нормального метаболизма костной ткани. Уровень ультрафиолетового облучения был недостаточен для равномерного синтеза холекальциферола D3 на протяжении всего года, а доступные при традиционном варианте хозяйствования продукты были бедны эргокальциферолом D2 и кальцием.

В качестве ответа на давление негативных факторов, отбором был подхвачен компенсаторный вариант регуляции минерального обмена в кости, при котором оптимизация обеспечивается за счёт носительства детерминирующих повышенную чувствительность тканей к витамину D генотипов VDR (CC*Fok1 и $\left.C T^{\star} F o k 1, G A^{*} B s m l\right)$.

В целом исследование показало, что генофонд горно-таёжных шорцев отражает антропоэкологическую специфику популяции: особенности среды обитания, характер традиционного природопользования и питания.

\section{Благодарности}

Работа выполнена в рамках НИР «Антропология евразийских популяций (биологические аспекты)» при частичной поддержке гранта РФФИ 18-09-00487.

\section{Библиография}

Антипова А.В. География России: эколого-географический анализ территории. М.: МНЭПУ, 2001. 208 с.

Антропоэкология Центральной Азии / под ред. Т.И. Алексеевой, В.А. Бацевича, Р.М. Мунчаева с соавт. М.: Научный мир, 2005. $328 \mathrm{c}$.

Атлас «Окружающая среда и здоровье населения России». М.: ПАИМС, 1995. 448 с.

Бабенко С.А., Алифрарова В.М., Орлова Ю.Ю., Пузырёв В.П. Связь аллельных вариантов гена VDR с рассеянным склерозом // Бюллетень сибирской медицины, 2008. № 5. С. 40-46. Балановская Е.В., Балаганская О.А., Дамба Л.Д. Дибирова Х.Д., Агджоян А.Т., Богунов Ю.В., Жабагин М.К., Исакова Ж.Т., Лавряшина М.Б.), Балановский О.П. Влияние природной среды на формирование генофонда тюркоязычного населения гор и степных предгорий Алтае-Саян, Тянь-Шаня и Памира // Вестник Московского университета. Серия XXIII. Антропология, 2014. № 2. C. 46-55.
Балановская Е.В., Жабагин М.К., Агджоян А.Т. Чухряева М.И. Маркина Н.В., Балаганская О.А., Схаляхо Р.А., Юсупов Ю.М., Утевская О.М., Богунов Ю.В., Асылгужин Р.Р., Долинина Д.О., Кагазежева Ж.А., Дамба Л.Д., Запорожченко В.В., Романов А.Г., Дибирова Х.Д., Кузнецова М.А., Лавряшина М.Б., Почешхова Э.А., Балановский О.П. Популяционные биобанки: принципы организации и перспективы применения в геногеографии и персонализированной медицине // Генетика, 2016. № 12. С. 1371-1387.

Кимеев В.М. Проблема этногенеза шорцев // Вестник Кемеровского государственного университета, 2014а. № 3 (59). Т. 3. C. 54-66.

Кимеев В.М. Русская колонизация как основа формирования шорского этноса // Вестник Кемеровского государственного университета, 20146. № 3 (59). Т. 3. С. 67-76.

Козлов А.И. Связанные с потреблением углеводных продуктов нутрициологические и генетические риски развития ожирения у коренных северян // Вопросы питания, 2019. Т. 88, № 1. С. 5-16.

Козлов А.И., Вершубская Г.Г. D-витаминный статус и персистенция лактазы в европейских популяциях (обзор литературы с элементами мета-анализа) // Вестник Московского университета. Серия XXIII. Антропология, 2017. № 3. С. 68-75. Козлов А.И., Вершубская Г.Г., Негашева М.А. Полиморфизм гена рецептора витамина D (VDR) в выборках населения Европейской России и Приуралья // Пермский медицинский журнал, 2016. Т. 33. № 5. С. 60-66.

Малярчук Б.А., Деренко М.В. Полиморфизм гена трегалазы (TREH) у коренного населения Сибири // Вавиловский журнал генетики и селекции, 2017. Т. 21. № 8. С. 964-968.

Мякоткин В.А., Крылов М.Ю., Гусева И.А. с соавт. Молекулярно-генетическое тестирование предрасположенности к остеопорозу у женщин в менопаузе в Москве // Научно-практическая ревматология, 2011. № 2. С. 15-20.

Огурцов А.Ю. Материалы военно-инженерной разведки 17451746 гг. на Алтае и в Саянах как источник по экономике коренных народов Южной Сибири // Кузнецкая старина. Новокузнецк: Кузнецкая крепость, 2008. Вып. 10. С. 159-165.

Потапов Л.П. Очерки по истории Шории. М.-Л.: Изд-во АН СCCP, 1936. $260 \mathrm{c}$

Потапов Л.П. Шорцы на пути социалистического развития // Советская этнография, 1950. № 3. С. 123-136.

Радлов В.В. Из Сибири: страницы дневника. М.: Наука, 1989. $749 \mathrm{c}$.

Селезнев А.Г. Конь и металл: экологические аспекты формирования лесных и таежных культур юга Сибири // Известия АлтГУ, 2009. №4. С. 191-195.

Соколова М.В., Васильев Е.В., Козлов А.И. Ребриков Д. В., Сенкеев С.С., Кожекбаева Ж.М., Люндуп А.В., Свечникова Н.С., Огурцов П.П., Хуснутдинова Э.К., Янковский Н.К., Боринская С.А. Полиморфизм С/Т-13910 регуляторного участка гена лактазы LCT и распространенность гиполактазии в популяциях Евразии // Экологическая генетика, 2007. Т. 5. № 3. C. 26-35.

Тагиева А.Н., Сметник В.П., Сухих Г.Т., Крылов М.Ю., Греченко А.В., Мякоткин В.А., Беневоленская Л.И. Изучение роли генов рецептора витамина D (VDR), б-рецептора эстрогенов (ESRб) и б-1-цепи коллагена 1-го типа (COLIAI) в заболеваемости остеопорозом у женщин в постменопаузе // Медицинская генетика, 2005. Т. 4. № 2. С. 90-95.

Улагашева И. Пища шорцев // Ежемесячный бюллетень «Туганчер», 1997. № 3 (45). Доступно по: http://tadarlar.ru/pishhashorcev.html (дата обращения: 28.10.2018).

Фролова И.Д. Факторы модернизации традиционного питания северных и южных алтайцев с конца XVIII по начало XXI в // Известия АлтГУ, 2007. № 4-3. С. 192-195. 
Химический состав пищевых продуктов / под ред. М.Ф. Нестерина и И.М. Скурихиной. М.: Пищевая промышленность, 1979. 247 c.

Цыганкова Д.П., Мулерова Т.А., Огарков М.Ю. с соавт. Основные принципы питания и пищевое поведение у современных жителей Горной Шории // Профилактическая медицина, 2016. № 4. С. 47-51.

Ядринцев Н.М. Сибирские инородцы, их быт и современное положение. СПб.: Издание И.М. Сибирякова, 1891. 308 с.

\section{Сведения об авторах}

Козлов Андрей Игоревич, д.б.н.;

ORCID ID: 0000-0002-6710-4862; dr.kozlov@gmail.com;

Остроухова Ирина Олеговна, ostrouhova.95@mail.ru;

Лавряшина Мария Борисовна, д.б.н. профессор;

ORCID ID: 0000-0003-1593-0676; Imb2001@mail.ru;

Вершубская Галина Григорьевна;

ORCID ID: 0000-0003-2452-1532; ggver@ya.ru;

Ульянова Марина Владиславовна, к.б.н.; ulmar2003@mail.ru.

Kozlov A.I. ${ }^{1,2)}$, Ostroukhova I.O.3), Lavryashina M.B. ${ }^{4)}$, Verdubskaya G.G., ${ }^{1,2)}$, Ulyanova M.V. ${ }^{3)}$

1) Lomonosov Moscow State University, Anuchin Research Institute and Museum of Anthropology, Mokbovaya st, 11, Moscow, 125009, Russia;

2) Institute of Developmental Physiology, Russian Academy of Education, Pogodinskaya st, 8-2, Moscow, 119121, Russia;

3) Kemerovo State University, Krasnaya st, 6, Kemerovo, 650000, Russia;

4) Kemerovo State Medical University, Voroshilov st, 22A, Kemerovo, 650056, Russia

\section{ANTHROPOLOGICAL AND ECOLOGICAL SPECIFICITY OF POLYMORPHISM IN GENES RELATED TO BONE TISSUE METABOLISM (AS EXEMPLIFIED BY THE SHORS PEOPLE)}

Introduction. We studied the association between the frequencies of genetic variants affecting bone metabolism and environmental and traditional dietetic features in a group of Mountain-Taiga Shors.

Materials and methods. A total of 72 samples (37 males, 35 females) for molecular-genetic testing have been collected from Shors of Kemerovo Oblast. We performed genotyping for the VDR BsmI rs1544410, VDR Fok1 rs2228570, TREH rs2276064, and LCT rs4988235 genes. The data on the traditional foods and their main sources were obtained from the ethnographical literature.

Results and discussion. At the latitude of Southern Siberia $\left(52^{\circ} \mathrm{N}\right)$ the human body cannot synthesize the necessary quantity of cholecalciferol (D3) throughout the year. There were few food sources of ergocalciferol (D2) in the traditional diet of the Shors: freshwater fish, mare's and sheep's milk provided inconsiderable intake. Mushrooms, a potential source of vitamin D2, were not an essential element of the traditional diet. That is consistent with the fact that the frequencies of genotypes $A A^{*} T R E H(6.9 \%)$ and AG*TREH (27.8\%), associated with the minimal and reduced activity of the enzyme trehalase, necessary for the assimilation of mushroom disaccharide trehalose, are relatively high among the Shors. Thus, the people had apparently experienced chronical vitamin $D$ insufficiency.

The milk of domestic animals, as a source of calcium, took a small place in the traditional diet: until the 1930s Shors had not kept cows. We found that the CC*LCT genotype that determines the limited lactase activity and milk intolerance in adults accounts for $73.6 \%$ in the study group. It is considered as high: in various groups of Russians, the percentage fluctuates in the range of $40-50 \%$. The low availability of milk and the lack of other calcium-containing products constituted the risk factor for insufficient bone mineralization, which agrees with anthropological materials.

An evolutionary response to the pressure of the negative factors was an increase in the proportion of the VDR CC*Fok1 (44.4\%), CT*Fok1 (15.3\%), GA*Bsml (48.6\%) genotypes that associate with higher calcium absorption in the bone.

Conclusion. It may be concluded that the Shors adapted to the conditions of low vitamin $D$ and calciumcontaining products availability by developing the higher sensibility of tissue receptors to vitamin D.

Keywords: anthropology; genetics; diet; bone mineralization; vitamin D receptor; ergocalciferol, D2; cholecalciferol, D3; lactase; trehalase

АНТРОПОЛОГИЯ № 2/2019: 107-115

Anthropology, 2019, no. 2, pp. 107-115
Вестник Московского университета. Серия ХХIII Moscow University Anthropology Bulletin 


\section{References}

Antipova A.V. Geografiya Rossii: ekologo-geograficheskij analiz territorii [Geography of Russia: ecological and geographical analysis of territory]. Moscow: MNEPU Publ., 2001. 208 p. (in Russ.).

Antropoekologiya Tsentralnoy Azii / pod red. T.I.Alekseyevoy. V.A.Batsevicha. R.M.Munchayeva $i$ dr. [Anthropological Ecology of Central Asia]. Moscow: Nauchny Mir Publ., 2005. 328 p. (in Russ.). Atlas "Okruzhayuschaya sreda i zdorov'e naseleniya Rossii» [Atlas «Environment and health of the population of Russia»]. Moscow, PAIMS Publ., 1995. 448 p. (In Russ.)

Babenko S.A., Alifarova V.M., Orlova Yu.Yu., Puzyryov V.P. Svyaz allel'nyh variantov gena VDR s rasseyannym sklerozom [Connection of allelic variants of VDR gene with multiple sclerosis]. Byulleten sibirskoj mediciny [Bulletin of Siberian medicine], 2008, 5, pp. 40-46. (In Russ.).

Balanovskaya E.V., Balaganskaya O.A., Damba L.D., Dibirova Kh.D., Agjoyan A.T., Bogunov Yu.V., Zhabagin M.K., Isakova J.T., Lavryashina M.B., Balanovskij O.P. Vliyanie prirodnoj sredy na formirovanie genofonda tyurkoyazychnogo naseleniya gor i stepnyh predgorij Altae-Sayan, Tyan'-Shanya i Pamira [The influence of natural environment on the gene pool of Turkic-speaking population of the Altai-Sayan, Tien Shan and Pamir mountains and steppe foothills]. Vestnik Moskovskogo universiteta. Seriya XXIII. Antropologiya [Moscow University Anthropology Bulletin], 2014, 2, pp. 46-55. (In Russ.).

Balanovskaya E.V., Zhabagin M.K., Agdzhoyan A.T.Markina N.V., Balaganskaya O.A., Skhalyaho R.A., Yusupov Yu.M., Utevskaya O.M., Bogunov Yu.V., Asylguzhin R.R., Dolinina D.O., Kagazezheva ZH.A., Damba L.D., Zaporozhchenko V.V., Romanov A.G., Dibirova H.D., Kuznecova M.A., Lavryashina M.B., Pocheshkhova E.A., Balanovskij O.P. Populyacionnye biobanki: principy organizacii i perspektivy primeneniya $v$ genogeografii i personalizirovannoj medicine [Population biobanks: principles of organization and prospects for application in genogeography and personalized medicine]. Genetika [Genetics], 2016, 12, pp. 1371-1387. (In Russ.).

Kimeyev V.M. Problema etnogeneza shortsev [Problem of Shors' ethnogenesis]. Vestnik Kemerovskogo gosudarstvennogo universiteta [Bulletin of Kemerovo State University], 2014a, 3 (59), pp. 54-66. (In Russ.).

Kimeev V.M. Russkaya kolonizaciya kak osnova formirovaniya shorskogo etnosa [The Russian colonization as the forming factor of the ethnos the Shors], Vestnik Kemerovskogo gosudarstvennogo universiteta [Bulletin of Kemerovo State University]. 2014b, 3 (59), pp. 67-76. (In Russ.).

Kozlov A.I. Svyazannye s potrebleniem uglevodnyh produktov nutriciologicheskie i geneticheskie riski razvitiya ozhireniya u korennyh severyan [Carbohydrate-related nutritional and genetic risks of obesity for indigenous northerners]. Voprosy pitaniya [Problems of Nutrition], 2019, 88 (1), pp. 5-16. (In Russ.). Kozlov A.I., Vershubskaya G.G. D-vitaminnyj status i persistenciya laktazy $v$ evropejskih populyaciyah (obzor literatury s elementami meta-analiza) [D-vitamin status and lactase persistence in European populations (review with the elements of meta-analysis)]. Vestnik Moskovskogo Universiteta. Seriya XXIII. Antropologiya [Moscow University Anthropology Bulletin], 2017, 3, pp. 68-75. (In Russ.). Kozlov A.I., Vershubskaya G.G., Negasheva M.A. Polimorfizm gena receptora vitamina $D(V D R) \vee v y b o r k a h$ naseleniya Evropejskoj Rossii i Priural'ya [Polymorphism of vitamin D receptor (VDR) gene in sampling of European Russia and Priuraliye population]. Permskij medicinskij zhurnal [Perm Medical Journal], 2016, 33 (5), pp. 60-66. (In Russ.)

Malyarchuk B.A., Derenko M.V. Polimorfizm gena tregalazy (TREH) u korennogo naseleniya Sibiri [Polymorphism of trehalase gene (TREH) in native populations of Siberia], Vavilovskij zhurnal genetiki i selekcii [Vavilov Journal of Genetics and Breeding], 2017, 21 (8), pp. 964-968. (In Russ.).
Myakotkin V.A., Krylov M.Yu., Guseva I.A. et al. Molekulyarnogeneticheskoe testirovanie predraspolozhennosti k osteoporozu u zhenshchin $v$ menopauze $v$ Moskve [Molecular genetic testing of osteoporosis susceptibility in postmenopausal women in Moscow]. Nauchno-prakticheskaya revmatologiya [Sciencepractical rheumatology], 2011, 2, pp. 15-20. (In Russ.).

Ogurcov A.Yu. Materialy voenno-inzhenernoj razvedki $1745-1746 \mathrm{gg}$ na Altae i v Sayanah kak istochnik po ekonomike korennyh narodov Yuzhnoj Sibiri [Reports of military engineer intelligence service in the Altai and Sayan Mountains in $1745-1746$ as a data source on economy of indigenous peoples of Southern Siberia]. Kuzneckaya starina [Kuznetsk past]. Novokuzneck: Kuzneckaya krepost' Publ., 10, pp. 159-165. (In Russ.).

Potapov L.P. Ocherki po istorii Shorii [Essays on history of Shoria] Moscow-Leningrad: AN SSSR Publ., 1936, 260 p. (In Russ.).

Potapov L.P. Shorcy na puti socialisticheskogo razvitiya [The Shors on the path of Socialist development], Sovetskaya etnografiya [Soviet Ethnography], 1950, 3, pp. 123-136. (In Russ.).

Radlov V.V. Iz Sibiri: Stranitsy dnevnika [From Siberia: Diary pages]. Moscow: Nauka Publ., 1989, 749 p. (In Russ.).

Seleznev A.G. Kon' i metall: ekologicheskiye aspekty formirovaniya lesnykh i tayezhnykh kul'tur yuga Sibiri [Horse and metal: environmental aspects of the forming of forest and taiga cultures in South Siberia], Izvestiya AltGU [Proceedings of Altai State University], 2009, 4, pp. 191-195. (In Russ.).

Sokolova M.V., Vasil'yev Ye.V., Kozlov A.I., Rebrikov D. V., Senkeev S.S., Kozhekbaeva ZH.M., Lyundup A.V., Svechnikova N.S. Ogurcov P.P., Husnutdinova E.K., YAnkovskij N.K., Borinskaya S.A. Polimorfizm C/T-13910 regulyatornogo uchastka gena laktazy LCT i rasprostranennost' gipolaktazii $v$ populyatsiyakh Yevrazii [Polymorphism C/T-13910 of LCT gene regulatory region and lactase deficiency in Eurasian populations], Ekologicheskaya genetika [Ecological Genetics], 2007, 5 (3), pp. 26-35. (In Russ.). Tagiyeva A.N., Smetnik V.P., Sukhikh G.T., Krylov M.YU., Grechenko A.V., Myakotkin V.A., Benevolenskaya L.I. Izucheniye roli genov retseptora vitamina $D(V D R)$, a-retseptora estrogenov (ESRa) i 6-1-tsepi kollagena 1-go tipa (COLIAI) v zabolevayemosti osteoporozom u zhenshchin v postmenopauze [The role of vitamin $D$ receptor (VDR), estrogen receptor $\sigma$ (ESRб), and alpha-1-chain collagen type 1 (COLIAI) genes in the incidence of osteoporosis in postmenopausal women], Meditsinskaya genetika [Medical Genetics], 2005, 4(2), pp 90-95. (In Russ.).

Ulagasheva I. Pishcha shortsev [Diet of the Shors], Yezhemesyachnyy byulleten' "Tugancher» [“Tougancher” Monthly Bulletin], 1997, 3(45). Accessed: http://tadarlar.ru/pishha-shorcev.html. Link active on 10/ 28/2018. (In Russ.)

Frolova I.D. Faktory modernizatsii traditsionnogo pitaniya severnykh i yuzhnykh altaytsev $\mathrm{s}$ kontsa XVIII po nachalo XXI v [Factors of modernization of traditional diet of northern and southern Altaians from the late 18th to the early 21st century], Izvestiya AltGU [Proceedings of Altai State University], 2007, 4-3, pp. 192-195. (In Russ.).

Khimicheskiy sostav pishchevykh produktov [Chemical composition of food], pod red. M.F. Nesterina i I.M. Skurikhinoy. Moscow, Pishchevaya promyshlennost' [Food Industry Publ.], 1979. 247 p. (In Russ.).

Tsygankova D.P., Mulerova T.A., Ogarkov M.Yu., et al. Osnovnyye printsipy pitaniya i pishchevoye povedeniye u sovremennykh zhiteley Gornoy Shorii [Basic principles of diet and nutritional behaviors among contemporary residents of Mountain Shoria], Profilakticheskaya meditsina [Preventive Medicine], 2016, 4, pp. 4751. (In Russ.).

Yadrintsev N.M. Sibirskiye inorodtsy, ikh byt i sovremennoye polozheniye [Non-Slavic Siberian dwellers, their way of life and current situation], St-Petersberg, I.M. Sibiryakov Publ., 1891. 308 p. (in Russ.).

Ames S.K., Ellis K.J., Gunn S.K., et al. Vitamin D receptor gene Fok1 polymorphism predicts calcium absorption and bone mineral density in children. J. Bone Mineral Res., 1999, 14 (5), pp. 740-746. 
Brot C., Vestergaard P., Kolthoff N., et al. Vitamin D status and its adequacy in healthy Danish perimenopausal women: relationships to dietary intake, sun exposure and serum parathyroid hormone. Brit. J. Nutr., 2001, 86 (Suppl.1), pp. 97-103.

Dawson-Hughes B., Harris S., Finneran S. Calcium absorption on high and low calcium intakes in relation to vitamin $D$ receptor genotype. J. Clin. Endocrinol. Metab., 1995, 80, pp. 3657-3661.

Ferrara M., Matarese S. M. R., Francese M., et al. Effect of VDR polymorphisms on growth and bone mineral density in homozygous beta thalassaemia. Brit. J. Haematol., 2002, 117, pp. 436-440.

Grundberg E., Brandstrom H., Ribom E.L., et al. Genetic variation in the human vitamin $D$ receptor is associated with muscle strength, fat mass and body weight in Swedish women. Eur. J. Endocrinol., 2004, 150, pp. 323-328.

Ingram C.J., Mulcare C.A., Itan Y., et al. Lactose digestion and the evolutionary genetics of lactase persistence. Hum. Genet., 2009, 124 (6), pp.579-591.

Kozlov A., Vershubsky G., Borinskaya S., et al. Activity of disaccharidases in Arctic populations: Evolutionary aspects. $J$. Physiol. Anthropol., 2005, 24, pp. 473-476.

Kozlov A.I., Vershubsky G.G., Ateeva Yu.A., et al. Association of vitamin $D$ receptor gene with anthropometric measures in Komi ethnic group. Russ. J. Genet.: Applied Res., 2014, 4(5), pp. 397-404.

Kozlov A.I., Vershubskaya G.G. Blood serum 25-Hydroxyvitamin $D$ in various populations of Russia, Ukraine, and Belarus: A systematic review with elements of meta-analysis. Human Physiology, 2017, 43 (6), pp. 135-146.

Kozlov A.I., Vershubskaya G.G., Negasheva M.A. Association between relative bone mass and vitamin $D$ receptor gene polymorphism. Human Physiology, 2017, 43 (3), pp. 320-325.

Larcombe L.A., Orr P.H., Lodge A.M., et al. Functional gene polymorphisms in Canadian Aboriginal populations with high rate of tuberculosis. I. J. D., 2008, 198, pp. 1175-1179.
Muller Y.L., Hanson R.L., Knowler W.C., et al. Identification of genetic variation that determines human trehalase activity and its association with type 2 diabetes. Hum. Genet., 2013, 132, pp. 697-707.

Richards A.B., Krakowka S., Dexter L.B., et al. Trehalose: a review of properties, history of use and human tolerance, and results of multiple safety studies. Food Chem. Toxicol., 2002, 40 (7), pp. 871898.

Smith G.D., Lawlor D.A., Timpson N.J., et al. Lactase persistencerelated genetic variant: population substructure and health outcomes. Eur. J. Hum. Genet., 2009, 17 (3), pp. 357-367.

Souci S.W., Fachmann W., Kraut H. Die Zusammensetzung der Lebensmittel-Nohrwerttabellen 1989/90, 4. Auflage. Stuttgart, Wissenschaftliche Verlagsgesellschaft mbH, 1989. pp.1028.

Suda T., Ueno Y., Fujii K., Shinki T. Vitamin D and bone. J. Cell Biochem., 2003, 88, pp. 259-266.

Uitterlinden A.G., Fang Y., van Meurs J.B.J., et al. Genetics and biology of vitamin D receptor polymorphisms: Review. Gene, 2004, 338, pp. 143-156.

\section{Information about Authors}

Kozlov Andrew I., PhD, D.Sc;

ORCID ID: 0000-0002-6710-4862; dr.kozlov@gmail.com;

Ostrouhova Irina; ostrouhova.95@mail.ru;

Lavryashina Mariya B., PhD, DSc, professor;

ORCID ID: 0000-0003-1593-0676; Imb2001@mail.ru;

Vershubskaya Galina; ORCID ID: 0000-0003-2452-1532; ggver@ya.ru;

Uljanova Marina, PhD; ulmar2003@mail.ru. 